\title{
Effect of preozonation on the characteristic transformation of fulvic acid and its subsequent trichloromethane formation potential: Presence or absence of bicarbonate
}

\author{
Jing $\mathrm{Li}^{\mathrm{a}}{ }^{\mathrm{a}, \mathrm{b}}$, Huijuan $\mathrm{Liu}^{\mathrm{a}, *}, \mathrm{Xu}$ Zhao ${ }^{\mathrm{a}}$, Jiuhui $\mathrm{Qu}^{\mathrm{a}, *}$, Ruiping Liu ${ }^{\mathrm{a}}$, Jia $\mathrm{Ru}^{\mathrm{a}, \mathrm{b}}$ \\ ${ }^{\text {a }}$ State Key Laboratory of Environmental Aquatic Chemistry, Research Center for Eco-Environmental Sciences, \\ Chinese Academy of Sciences, Beijing 100085, China \\ ${ }^{\mathrm{b}}$ Graduate University, Chinese Academy of Sciences, Beijing 100039, China
}

Received 29 August 2007; received in revised form 13 January 2008; accepted 14 January 2008

Available online 6 March 2008

\begin{abstract}
The effects of bicarbonate on the characteristic transformation of fulvic acid (FA) and its subsequent trichloromethane formation potential (TCMFP) were investigated in the process of preozonation. Dissolved organic carbon (DOC) removal rate and the residual aqueous ozone concentration during preozonation were measured with different bicarbonate concentration. The presence of bicarbonate inhibited DOC removal and decreased TCMFP yields in the initial oxidation period. In order to explain these phenomena, the molecular weight $(\mathrm{MW})$ distribution $(<5,5-10,10-30$, and $>30 \mathrm{kDa})$ and corresponding TCMFP were investigated for FA and its subsequent oxidation products. Furthermore, transformation of molecular structure, based on MW distribution, was also characterized with Fourier transform infrared (FTIR) spectrum. Bicarbonate showed different inhibiting effects on TCMFP of organic species with different MW, and more significant TCMFP decrement was observed for the high MW fraction $(>30 \mathrm{kDa})$ than for the low MW fractions. Preozonation led to obvious reduction on DOC and $\mathrm{UV}_{254}$ in most of MW fractions wherever bicarbonate was present or not, demonstrating that ozone contributed to both organics mineralization and structure variation, synchronously. As being indicated from the results of FTIR and gas chromatography-mass spectrometry, the functional groups such as alcohols, epoxides and phenols, the formation of which was promoted with hydroxyl radicals $(\cdot \mathrm{OH})$ and would be remarkably inhibited by bicarbonate, were responsible for the increment of TCM precursor's concentration during ozonation. Results of these studies confirmed low dosage bicarbonate affecting the ozonation pathways, influencing the intermediate species formation and impacting its subsequent TCMFP yields through inhibiting the ${ }^{\circ} \mathrm{OH}$ radicals reactions mainly occurred in high MW fractions.
\end{abstract}

(C) 2008 Elsevier Ltd. All rights reserved.

Keywords: Ozonation; Bicarbonate; TCMFP; Molecular weight (MW) distribution; Fourier transform infrared (FTIR) spectrum

\section{Introduction}

Chlorine is widely used as disinfectant in drinking water treatment to inactivate microorganisms as bacteria, virus and algae. The disinfection by-products (DBPs), such as trihalomethanes, formed in the reaction between chlorine and natural organic matter (NOM), have been detected and caused the public health concern for their carcinogenic

\footnotetext{
${ }^{*}$ Corresponding authors. Tel.: +861062849151; fax: +86 1062923558.

E-mail addresses: hjliu@rcees.ac.cn (H. Liu),jhqu@rcees.ac.cn (J. Qu).
}

characteristic since 1970s (Rook, 1974). The enhanced removal of DBP precursors, prior to chlorination process, is an alternative method to control or avoid the formation of DBPs. The pre-oxidation, especially preozonation, has received more attention in recent years than before (Chang et al., 2002).

There is a strong distinction in estimating the capability of preozonation to remove DBP precursors. Some researchers (Lykins et al., 1994; Chang et al., 2002) revealed that preozonation reduced the DBP formation potential (DBPFP) of NOM due to the decrease of the strength of aromatic $\mathrm{C}=\mathrm{C}$ 
structure within NOM after ozonation. However, other researchers reported the enhancement of DBPFP during ozonation due to the different oxidation conditions (Reckhow et al., 1986; Ko et al., 2000).

Furthermore, the composition in water can influence the reaction processes in ozonation system (Buxton et al., 1988; Arslan-Alaton et al., 2002). In fact, alkalinity, being one of the most common components in natural water, is confirmed to show the inhibiting effect on ozonation process (Hofmann and Andrew, 2006). Although the effect of bicarbonate on DBP precursors during ozonation has been received a lot of attention (Reckhow et al., 1986), few studies focused on the effects of bicarbonate on structure characteristics transformation of DBP precursors during ozonation.

The objective of this research is to investigate the effects of weak alkalinity (bicarbonate) on the characteristics variation of fulvic acid (FA) and the subsequent trichloromethane formation potential (TCMFP) during ozonation. Based on the obtained results, the possible mechanisms involved in these processes were also investigated.

\section{Materials and methods}

\subsection{Materials}

All chemical solutions were prepared from reagent grade chemicals or stock solutions. Sodium hypochlorite (NaO$\mathrm{Cl}>10 \%$ available chlorine) was used as the source of chlorine. Commercial FA (Henan ChangSheng Co.) was employed as model pollutant in this study.

\subsection{Ozonation tests}

FA solution was prepared by dissolving FA powder into 31 deionized water directly, and then filtered through $0.45 \mu \mathrm{m}$ membranes without further purification. The dissolved organic carbon (DOC) concentration of FA solution was determined to be $3.0 \pm 0.2 \mathrm{mg}^{-1}$. The $\mathrm{pH}$ of FA solution was adjusted to $8.2 \pm 0.2$ by $0.1 \mathrm{M} \mathrm{NaOH}$ and $0.05 \mathrm{M} \mathrm{H}_{2} \mathrm{SO}_{4}$. The obtained FA solution (3.01) was used for ozonation experiments.

Ozonation tests were carried out in a batch glass reactor (3.0 1) equipped with magnetic mixer at $20 \pm 3{ }^{\circ} \mathrm{C}$. Each set of semi-batch test was carried out by continuously introducing ozone into the batch reactor. Ozone was produced by a laboratory scale ozone generator (ozonizer series OS-N, MISUBISHI) and introduced into 3.01 model solution at an inlet dosage rate of $1.8 \mathrm{mg} \mathrm{O}_{3} \mathrm{~min}^{-1}$ directly. The dosage rate of ozone $\left(1.8 \mathrm{mg} \mathrm{O}_{3} \mathrm{~min}^{-1}\right)$ was kept constant throughout this study. Sodium bicarbonate ranging from 0 to $11.90 \mathrm{mM}$ was added into reactor before ozonation. Water samples were withdrawn from the reactor at prescribed intervals during ozonation $(50 \mathrm{~min})$. The dissolved $\mathrm{O}_{3}$ in the water samples was removed by high-purity nitrogen gas purge immediately. Then, the samples were stored at $4{ }^{\circ} \mathrm{C}$ before being analyzed. Meantime, the residual ozone concentration in reaction was analyzed.

\subsection{Ultrafiltration tests}

Ultrafiltration was carried out on the samples taken from the ozonation reactor. Filtration experiments were conducted in a stirred cell (Model 8200, Amicon Corp., Beverly, MA) connected to a reservoir filled with highpurity nitrogen at a temperature of $20 \pm 1{ }^{\circ} \mathrm{C}$. The water samples were fractioned by using "PL series" type membranes (regenerated cellulose) with molecular weight cutoffs of 30,10, and $5 \mathrm{kDa}$, respectively (Hua and Reckhow, 2007). Before filtration, these membranes were flushed with Milli-Q water to reduce the DOC or UV spectrum interference of solution. The solution was kept with the same ionic strength of $14.76 \mathrm{mM}$ by adding sodium bicarbonate $(4.76 \mathrm{mM})$ and sodium chloride $(10 \mathrm{mM})$ before ultrafiltration. The fractions concentrated by the ultrafiltration were distilled to the same volume before analyzing their DOC, UV spectra and TCMFP.

\subsection{TCMFP tests}

The samples withdrawn from ozonation reactor were chlorinated with sodium hypochlorite at $\mathrm{pH} 7$, buffered by $\mathrm{KH}_{2} \mathrm{PO}_{4} / \mathrm{NaOH}$ and incubated in $50 \mathrm{ml}$ chlorine demand-free, glass-stopped glass vials with head-free in the dark at $25 \pm 0.5^{\circ} \mathrm{C}$ for $24 \mathrm{~h}$. After removing the residual chlorine by $\mathrm{Na}_{2} \mathrm{SO}_{3}$, TCM concentrations were measured by gas chromatography/electron capture detector (GC/ECD) analysis.

\subsection{Analysis methods}

The solution's $\mathrm{pH}$ was measured by using Orion 720 APLUS Benchtop meter (Thermo Orion Co., USA). The concentration of unsaturated bonds was determined by measuring the absorbance at $254 \mathrm{~nm}$ wavelength by U3010 UV-vis spectrophotometer (Hitachi Co., Japan) equipped with $10 \mathrm{~mm}$ quartz cuvettes. The DOC concentration in water was measured by a multi N/C 3000 total organic carbon analyzer (Analytik Jena AG, Germany) after filtering the solution through a $0.45 \mu \mathrm{m}$ membrane. The ozone concentration in water was measured in $600 \mathrm{~nm}$ (adsorption of UV light on $600 \mathrm{~nm}$ ) by potassium indigo trisulfonate $\left(\mathrm{C}_{16} \mathrm{H}_{7} \mathrm{~N}_{2} \mathrm{O}_{11} \mathrm{~S}_{3} \mathrm{~K}_{3}\right)$ and the gas ozone concentration was detected by KI titration. Solid-state Fourier transform infrared (FTIR) spectra were recorded by a FTIR spectrometer (Thermo Nicolet NEXUS 670 FTIR). The spectra of electron spin resonance (ESR) of the hydroxyl radicals $\left({ }^{\circ} \mathrm{OH}\right)$ were detected by the electron spin resonance ESP 300E (Bruker Co., Germany).

The pretreatment procedure for TCM was performed according to USEPA method 551.1 (EPA, 1998). TCM samples were extracted by liquid/liquid extraction with hexane, and analyzed by GC/ECD (Agilent 6890N Series, USA) with 
$30 \mathrm{~m} \times 0.32 \mathrm{~mm} \times 0.25 \mu \mathrm{m}$ HP-5 capillary column. The column was heated from $35^{\circ} \mathrm{C}$ (holding time $4 \mathrm{~min}$ ) to $260{ }^{\circ} \mathrm{C}$, with a ramp of $10^{\circ} \mathrm{C} \mathrm{min}^{-1}$. The temperature of injector and detector was $200{ }^{\circ} \mathrm{C}$ and $290^{\circ} \mathrm{C}$, respectively. Nitrogen was used as carrier gas.

The half polar and polar organic compounds in the solution were pre-treated according to USEPA method 625 (EPA, 1984). The half polar organic compounds were measured by gas chromatography/mass spectrometry (GC/MS) (Agilent 6890N Series /5973 MSD, USA) with $30 \mathrm{~m} \times 0.32 \mathrm{~mm} \times 0.25 \mu \mathrm{m}$ HP-5 capillary column. Helium was used as carrier gas. The column was heated from $40{ }^{\circ} \mathrm{C}$ (holding time $3 \mathrm{~min}$ ) to $280^{\circ} \mathrm{C}$, with a ramp of $10^{\circ} \mathrm{C} \mathrm{min}-1,4 \mathrm{~min}$ at $280{ }^{\circ} \mathrm{C}$. The temperature of injector was $250^{\circ} \mathrm{C}$. Source temperature was held at $250^{\circ} \mathrm{C}$, ionization energy at $70 \mathrm{eV}$ (electron ionization). Mass spectra were obtained in full scan mode.

The solvent of polar organic compounds were changed to hexane and derived by N, O-bis (trimethylsilyl) trifluoroacetamide ( $1 \%$ trimethylchlorosilane) for $2 \mathrm{~h}$ at $70{ }^{\circ} \mathrm{C}$. The derived samples were measured by the same GC/MS with $60 \mathrm{~m} \times 0.32 \mathrm{~mm} \times 0.25 \mu \mathrm{m}$ HP-5 capillary column. Helium was used as carrier gas. The GC oven was programmed as follows: 3 min at $50{ }^{\circ} \mathrm{C}$, first ramp $10^{\circ} \mathrm{C} \mathrm{min}^{-1}$ to $100^{\circ} \mathrm{C}, 5$ min at $100{ }^{\circ} \mathrm{C}$, second ramp $10^{\circ} \mathrm{C} \mathrm{min}^{-1}$ to $200^{\circ} \mathrm{C}, 2.5 \mathrm{~min}$ at $200^{\circ} \mathrm{C}$, third ramp $20^{\circ} \mathrm{C} \mathrm{min}^{-1}$ to $300{ }^{\circ} \mathrm{C}, 2.5 \mathrm{~min}$ at $300^{\circ} \mathrm{C}$. The $\mathrm{GC} /$ MS interface temperature was set at $300^{\circ} \mathrm{C}$. Mass spectra were obtained in full scan mode. The temperature of injector was $250{ }^{\circ} \mathrm{C}$. Source temperature was held at $250^{\circ} \mathrm{C}$, ionization energy at $70 \mathrm{eV}$ (electron ionization).

\section{Results}

\subsection{Effects of bicarbonate on DOC removal and residual aqueous ozone concentration}

Bicarbonate, being widely presented in natural water environment, had great influence on ozonation processes.

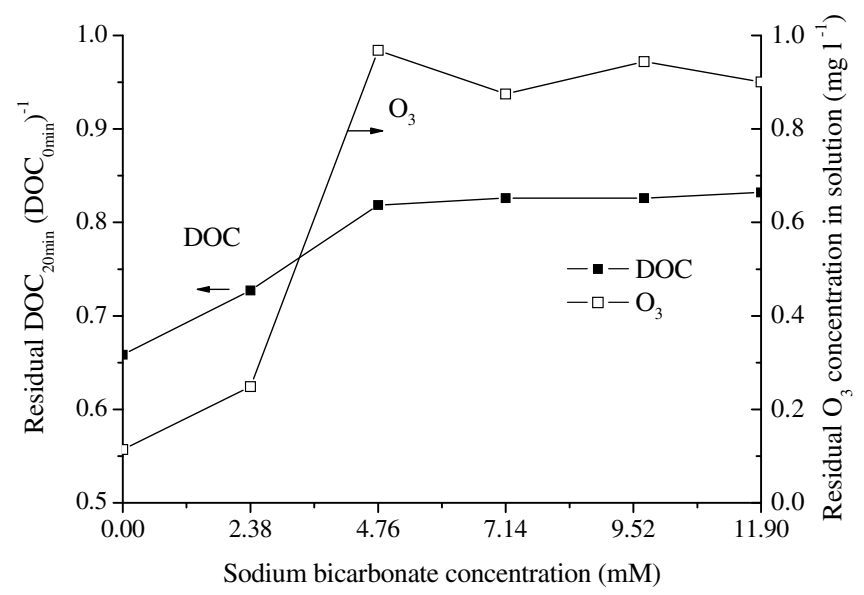

Fig. 1. Effect of bicarbonate on the residual DOC ratios $\left(\mathrm{DOC}_{20 \mathrm{~min}}\right.$ $\left(\mathrm{DOC}_{0 \mathrm{~min}}\right)^{-1}$ ) and residual $\mathrm{O}_{3}$ concentration in solution during ozonation (initial DOC: $3.0 \pm 0.1 \mathrm{mg} \mathrm{l}^{-1}, \mathrm{pH} 8.2 \pm 0.2,20 \pm 3^{\circ} \mathrm{C}, 1.8 \mathrm{mg} \mathrm{min}^{-1}$ ozone dosage rate, reaction time: $20 \mathrm{~min}$ ).
Fig. 1 shows the variation of residual DOC ratios and residual aqueous ozone concentration at different bicarbonate concentration (ozonation time is $20 \mathrm{~min}$ ). As indicated, when bicarbonate was absent, DOC removal was the highest to be $34 \%$, and the residual aqueous ozone concentration was as low as $0.11 \mathrm{mg}^{-1}$. With bicarbonate concentration increasing from 0 to $4.76 \mathrm{mM}$, the residual DOC ratio and residual aqueous ozone concentration steadily increased at the same ozone dosage $\left(1.8 \mathrm{mg} \mathrm{O}_{3} \mathrm{~min}^{-1}\right)$. After that point, the residual DOC ratio and the residual aqueous ozone concentration were relatively constant with increasing bicarbonate concentration. The residual DOC ratio was 0.82 and residual aqueous ozone concentration was $0.97 \mathrm{mg} \mathrm{l}^{-1}$ in the presence of $4.76 \mathrm{mM}$ bicarbonate. Previous studies had verified that bicarbonate inhibited 'OH radicals oxidations during ozonation. The amount of $4.76 \mathrm{mM}$ was the minimum dosage of scavengers to obtained maximum inhibiting effect on DOC removal, indicating that there were little available ${ }^{\circ} \mathrm{OH}$ radicals to mineralize the organic compounds in solution and the removal of DOC in the presence of $4.76 \mathrm{mM}$ bicarbonate was mainly attributed to the molecular ozone oxidations. Since bicarbonate could not affect the mineralization by molecular ozone, increasing the dosage of bicarbonate would not affect DOC removal anymore.

\subsection{Effects of bicarbonate on TCMFP yields}

Bicarbonate decreasing DOC removal of FA indicated the inhibiting effects of bicarbonate on ozonation. Then, TCMFP yields (TCMFP DOC $\left.{ }^{-1}\right)\left(\mu \mathrm{g}\left(\mathrm{mg}^{-1} \mathrm{C}\right)\right)$ of oxidation products with bicarbonate might be different from that without bicarbonate. In order to demonstrate the effects of bicarbonate on the subsequent TCMFP yields during ozonation, the chlorination was performed on the samples withdrawn from the ozonation with 0 and $4.76 \mathrm{mM}$ bicarbonate and their TCMFP yields was compared. The ozone dosage $\left(1.8 \mathrm{mg} \mathrm{O}_{3} \mathrm{~min}^{-1}\right)$ was kept constant in the experiments.

Fig. 2 presents the effects of bicarbonate on subsequent TCMFP yields as a function of ozonation time. As indicated, TCMFP yields all increased with ozonation time within $20 \mathrm{~min}$ and reached the highest value at $20 \mathrm{~min}$; after that, TCMFP yields began to decrease correspondingly. Differences of TCMFP yields in the presence or absence of bicarbonate were also observed. Firstly, after 20 min of ozonation, the decreasing rate of TCMFP yields with ozonation time was more rapid in the absence of bicarbonate than that in the presence of $4.76 \mathrm{mM}$ bicarbonate. Secondly, in the absence of bicarbonate, the peak value of TCMFP yields was $22.89 \mu \mathrm{g}\left(\mathrm{mg}^{-1} \mathrm{C}\right)$, which was about twice as much as that in the presence of bicarbonate.

These results indicated that TCM precursors were formed in the initial period of ozonation whether bicarbonate was present or not. And it was clearly observed that bicarbonate inhibited the TCM precursor's formation. It 


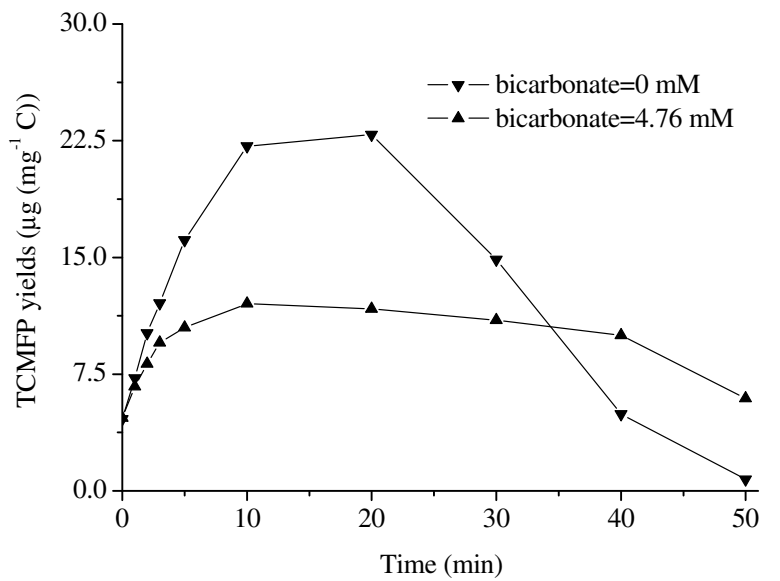

Fig. 2. Effect of bicarbonate on TCMFP yields (TCMFP DOC ${ }^{-1}$ ) of FA in ozonation process (ozonation: The concentration of bicarbonate was 0 and $4.76 \mathrm{mM}$, respectively, initial DOC: $3.0 \pm 0.1 \mathrm{mg} \mathrm{l}^{-1}, \mathrm{pH} 8.2 \pm 0.2$, $20 \pm 3{ }^{\circ} \mathrm{C}, 1.8 \mathrm{mg} \mathrm{min}^{-1}$ ozone dosage rate) (chlorination: the initial weight ratio of $\mathrm{NaOCl}\left(\right.$ as $\mathrm{Cl}_{2}$ ) to $\mathrm{DOC}$ was $3, \mathrm{pH} 7.0,24 \mathrm{~h}, 25.0 \pm 0.5^{\circ} \mathrm{C}$, darkly).

can be inferred that, the characteristics of ozonation products were remarkably different in the presence or absence of bicarbonate. The structure properties of these products would be discussed later in detail.

\subsection{Variation of $M W$ distribution of compounds during ozonation}

For the purpose of investigating the effects of bicarbonate on the variation of characteristics of organic species during ozonation, FA and its oxidation products (after 20 min of ozonation in the presence of bicarbonate (ozonation-pre) or absence of bicarbonate (ozonation-abs)) were fractionated into four fractions via sequential ultrafiltration. The DOC, $\mathrm{UV}_{254}$ and TCMFP concentration of the corresponding MW constituents of the three samples are presented in Fig. 3.

As shown in Fig. $3 a$ and $b$, significant changes between DOC and $U^{254}$ of each fraction in FA and its oxidation products were evident. DOC and $\mathrm{UV}_{254}$ concentration of each MW fraction of oxidation products was less than that of FA, except for the MW 5-10 kDa fraction. For ozonation-pre, the DOC concentration of MW 5-10 kDa fraction increased from 0.39 to $0.47 \mathrm{mg}^{-1}$ or the $\mathrm{UV}_{254}$ from 0.024 to $0.036 \mathrm{~cm}^{-1}$. These results were in accordance with the reports that the ozonation destructed the bonds in organics and transferred the larger MW organic species into smaller ones (Chiang et al., 2002). Thus, the organics cleaved from the high MW fraction were induced into the low MW fractions $(<10 \mathrm{kDa})$ and influenced the organics species in the low MW fractions. Additionally, it was observed in Fig. $3 a$ and $b$ that the concentration of DOC and $\mathrm{UV}_{254}$ of ozonation-abs were always less than that of ozonation-pre in each MW fraction, suggesting that bicarbonate inhibited the oxidation efficiency of ozonation in each MW fraction of organics.
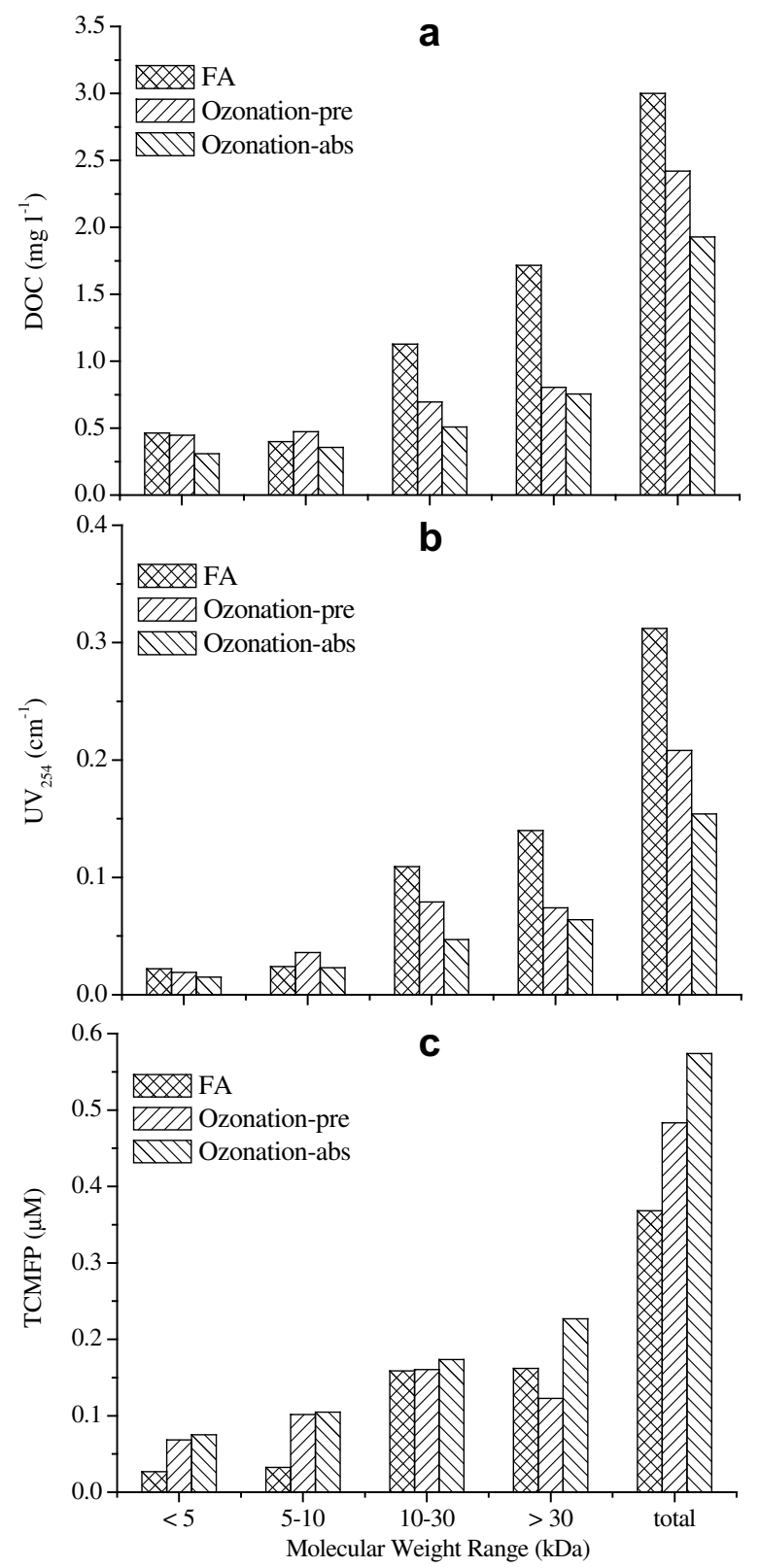

Fig. 3. DOC (a), $U_{254}$ (b) and TCMFP (c) of UF fractions in FA and its oxidation products in presence and absence of bicarbonate ( $\mathrm{a}$ and $\mathrm{b}$ ) initial DOC: $3.0 \pm 0.1 \mathrm{mg} \mathrm{l}^{-1}, \mathrm{pH} 8.2 \pm 0.2,20 \pm 3{ }^{\circ} \mathrm{C}, 1.8 \mathrm{mg} \mathrm{min}^{-1}$ ozone

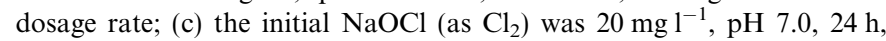
$25.0 \pm 0.5^{\circ} \mathrm{C}$, ozonation time: $20 \mathrm{~min}$, darkly).

Contrary to the trends of DOC and $\mathrm{UV}_{254}$, the TCMFP of most fractions in ozonation-pre and ozonation-abs increased after ozonation (Fig. 3c). These phenomena suggested that the amount of unsaturated bonds and DOC were not the proper indicator to determine the relative abundance of TCM precursors in these experiments and the ozonation had changed the structure of FA, which led to form more TCM precursors.

Furthermore, the effects of bicarbonate on TCMFP during ozonation were related with MW fractions. In detail, in the presence of $4.76 \mathrm{mM}$ bicarbonate, the TCMFP of the fraction with MW $>30 \mathrm{kDa}$ slightly decreased (24\%), while 
the TCMFP's increment of MW $<30 \mathrm{kDa}$ was as high as $151 \%$. Actually, Chiang et al. (2002) reported that TCMFP of low MW fraction increased through oxidizing the larger MW fractions into smaller ones in preozonation in the presence of alkalinity. The increment of TCM precursors in low MW fractions can be partly attributed to the small organics split from the high MW fractions and the products formed through the reactions between ozone and FA.

Interestingly, bicarbonate showed more significant effects on the fractions with higher MW $(>30 \mathrm{kDa})$ than that with lower MW $(<30 \mathrm{kDa})$ in inhibiting the formation of TCM precursors (Fig. 3c). In fact, for the fraction with MW $>30 \mathrm{kDa}$, there was an obvious increase $(40 \%)$ in ozonation-abs and a decrease $(24 \%)$ in ozonation-pre with regard to TCM precursors. Comparatively, no significant influence on the TCM precursor's formation was observed for the fractions with $\mathrm{MW}<30 \mathrm{kDa}$.

\section{Discussion}

\subsection{Effects of bicarbonate on distribution of oxidant species}

As it was reported, ozonation mainly is comprised of direct molecular ozone oxidations and indirect free radicals oxidations (Bothe et al., 1978). Consequently, the effects of bicarbonate on TCM precursors during ozonation could be attributed to these oxidation processes.

In our case, the production of ${ }^{\circ} \mathrm{OH}$ radicals in FA ozonation system was demonstrated through ESR spectra (Fig. 4). 'OH radicals may be produced via complex reactions between ozone and inorganic (e.g., ${ }^{\circ} \mathrm{OH}^{-}$) and organic species in solution (Gottschalk et al., 2002).

'OH radicals could react with bicarbonate with high reaction rate constant (Eq. (1)) (Buxton et al., 1988), which was much higher than that of the reaction between ${ }^{\circ} \mathrm{OH}$ radicals and most organic species

$\mathrm{HCO}_{3}^{-}+\cdot \mathrm{OH} \rightarrow \mathrm{CO}_{3}^{-}+\mathrm{H}_{2} \mathrm{O} \quad k_{1}=8.5 \times 10^{6} \mathrm{M}^{-1} \mathrm{~s}^{-1}$

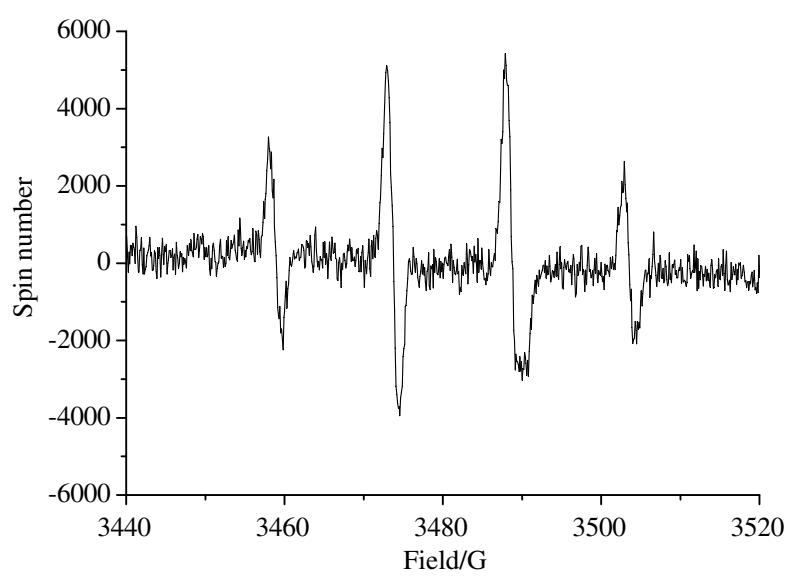

Fig. 4. ESR spectra in FA ozonation process system ( $\mathrm{pH} 8.2 \pm 0.2$, $20 \pm 3{ }^{\circ} \mathrm{C}, 0 \mathrm{mM}$ bicarbonate).
On the other hand, the carbonate radicals $\left(\mathrm{CO}_{3}^{-}\right)$inhibited the chain reactions for $\mathrm{OH}$ radicals formation and could not react with molecular ozone further. Therefore, aqueous ozone showed lower auto decomposition rate and accumulated more quickly in semi-batch reaction with bicarbonate than that in the absence of bicarbonate (Fig. 1). Consequently, the differences of DOC removal and TCMFP yields, between ozonation with 0 and $4.76 \mathrm{mM}$ bicarbonate, were mainly attributed to ${ }^{\circ} \mathrm{OH}$ radicals oxidations.

\subsection{FTIR characterization of structure variation during ozonation}

Previous studies implied the complicated reaction pathways involved in intermediate by-products formation during ozonation, and demonstrated the great impact of ozonation on subsequent TCM formation during chlorination. This portion aimed to investigate the structure variation during ozonation and to illustrate the possible pathways of TCM precursor's formation. Noteworthy, the $\mathrm{C}=\mathrm{C}$ and $\mathrm{C}-\mathrm{C}$ were the basic structure of $\mathrm{FA}$, and the changes of these functional groups could provide primary evidences to elucidate the pathways of TCM precursors' formation during ozonation. The FTIR was employed to illustrate the variation of these functional groups during ozonation.

\subsubsection{High $M W$ fractions}

Fig. 5 shows the FTIR spectra of $\mathrm{MW}>30 \mathrm{kDa}$ (Fig. 5a) and $\mathrm{MW}<30 \mathrm{kDa}$ (Fig. 5b) fractions of FA, ozonation-pre and ozonation-abs. The peaks located at $3700-3200 \mathrm{~cm}^{-1}$ (phenolic $\mathrm{O}-\mathrm{H}$ stretching), $3000-$ $2800 \mathrm{~cm}^{-1}$ (C-H stretching in methylene or methyl), $1720-1700 \mathrm{~cm}^{-1}$ (the asymmetric $\mathrm{C}=\mathrm{O}$ stretching in $\mathrm{COO}^{-}$ groups, and $-\mathrm{C}=\mathrm{O}$ including ketones), $1620 \mathrm{~cm}^{-1}$ (aromatic $\mathrm{C}=\mathrm{C}$ vibrations, $\mathrm{H}$-bonded $\mathrm{C}=\mathrm{O}$ of conjugated ketones), $1380-1400 \mathrm{~cm}^{-1}$ (anti-symmetric $\mathrm{COO}^{-}$stretching, or aliphatic $\mathrm{C}-\mathrm{H}$ deformation), near $1250 \mathrm{~cm}^{-1}$ (C-O stretching and $\mathrm{O}-\mathrm{H}$ deformation of $\mathrm{COOH}$; $\mathrm{C}-\mathrm{O}$ stretching in phenols) (Aiken et al., 1985; Silverstein and Webster, 1998), were the characteristic bands for the spectra of FA (Fig. 5a).

Generally, the intensity at $3000-2800 \mathrm{~cm}^{-1}$ increased due to ozonation, but the bands near $1620 \mathrm{~cm}^{-1}$ still remained in the samples (Fig. 5a). This information implied that the saturation of compounds was enhanced but the aromatic structures were not completely destructed during ozonation.

As for the FTIR spectra of ozonation-pre, the red-shift of peaks at $1620 \mathrm{~cm}^{-1}$ could be clearly observed, indicating that the poly-aromatic hydrocarbon was directly oxidized by molecular ozone to alkenes (Chang et al., 2002). The intensity at $1720 \mathrm{~cm}^{-1}$ increased with oxidation in the presence of bicarbonate, indicating the functional groups such as the carboxylic acids, aldehydes or ketones during 

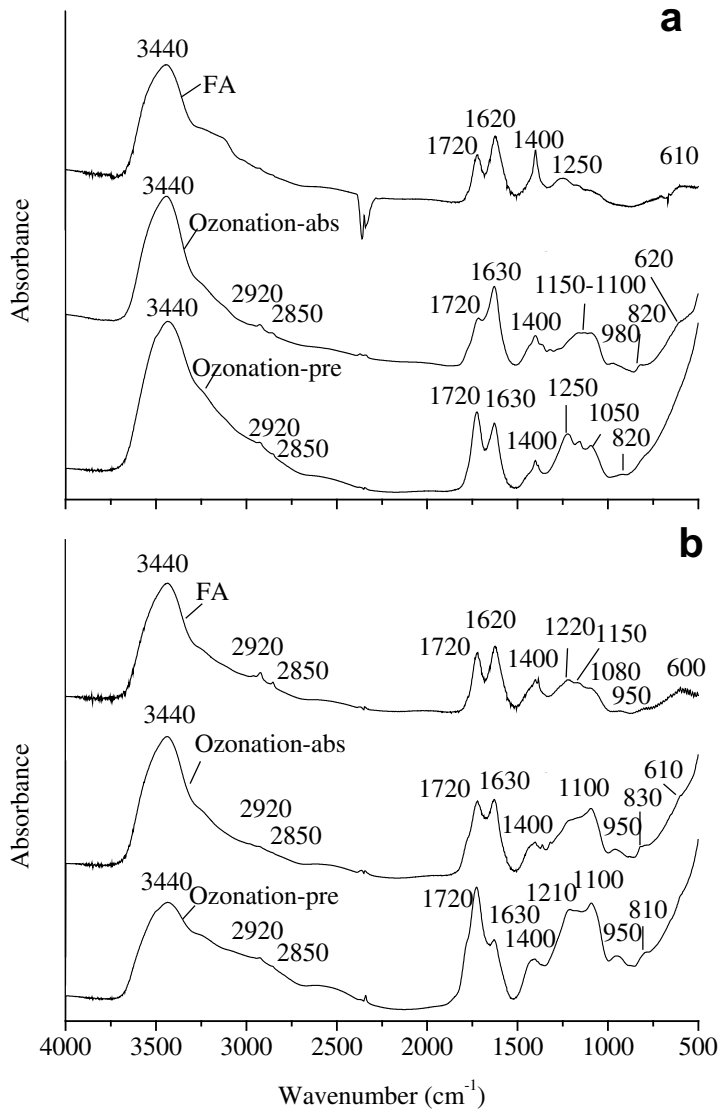

Fig. 5. FTIR spectra of MW fraction $>30 \mathrm{kDa}$ (a) and $<30 \mathrm{kDa}$ (b) of FA, ozonation-abs and ozonation-pre.

oxidation, was formed through the reactions of ozonolysis or ozone oxidation.

As for the FTIR spectra of ozonation-abs, there were new bands, such as $1200-1100 \mathrm{~cm}^{-1}$ (C-O stretching) and $900-800 \mathrm{~cm}^{-1}(\mathrm{C}-\mathrm{C}$ anti-symmetric ring stretching, $\mathrm{C}-\mathrm{H}$ stretching in aromatic structure) (Silverstein and Webster, 1998), implying that the intermediate products formed without bicarbonate were different from that with bicarbonate. The existence of strong bonds at 1200$1100 \mathrm{~cm}^{-1}$ demonstrated the formation of ethers, carbohydrates or alcohols in $\mathrm{OH}$ radicals oxidations. In addition, the weak peak at $900-800 \mathrm{~cm}^{-1}$ and the increment of intensity at $700-600 \mathrm{~cm}^{-1}(\mathrm{C}-\mathrm{H}$ out-of-plane deformation) were the indicators of the epoxides produced as a result of $\mathrm{OH}$ radicals oxidations (Fukushima and Tatsumi, 2001). Furthermore, the decrement in the intensity of bands at $1720 \mathrm{~cm}^{-1}$, indicated that ${ }^{\circ} \mathrm{OH}$ radicals converted carboxylic sites into $\mathrm{CO}_{2}$.

\subsubsection{Low $M W$ fractions}

The FTIR spectra of low MW fractions (Fig. 5b) differed from that of high MW fractions, indicating the distinct structure characteristics between organic species with different MW. The increment of intensity at 1200 $1100 \mathrm{~cm}^{-1}$ occurred for the products with low MW in pres- ence of bicarbonate, indicating the formation of $\mathrm{C}-\mathrm{O}$ structure. Combined with former results that the increment of TCMFP in inhibited oxidation was mainly ascribed to the fractions with low MW (Fig. 3c), it could be concluded that bicarbonate inhibited TCM precursor's formation via inhibiting $\mathrm{OH}$ radicals reactions to prevent the formation of organics with $\mathrm{C}-\mathrm{O}$ structure, such as ethers, carbohydrates, alcohols and epoxides.

\subsection{Pathways of TCM precursor's formation via molecular ozone and $\cdot \mathrm{OH}$ radicals}

\subsubsection{Molecular ozone reactions}

Reactions between molecular ozone and FA were accomplished by attacking the unsaturated moieties $\mathrm{C}=\mathrm{C}$ within FA through oxidation or ozonolysis (Reckhow and Singer, 1999). Actually, the formation of organics as ketones, carboxylic acids or carboxylic acids with $-\mathrm{OH}$ groups had also been demonstrated through GC/MS analysis in this study (Fig. 6).

The ozonation pathways noted above were similar to the initial reaction process in chlorination (Reckhow and Singer, 1984). Such intermediate products as ketones, which had less MW than FA, could easily react with chlo-
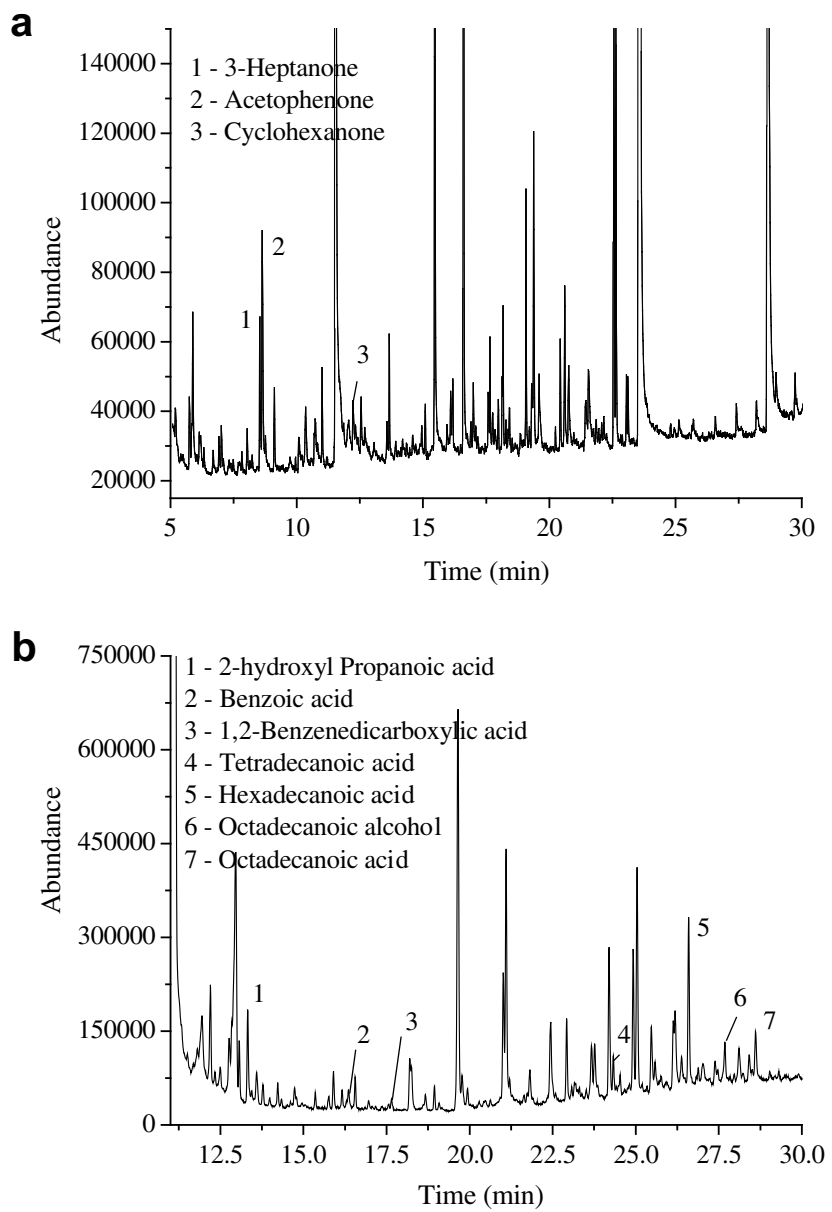

Fig. 6. Total ion chromatogram of half polar organics (a) and polar organics (b) in reactor after ozonation detected by GC/MS. 
rine and contribute to TCM formation (Rook, 1974; Reckhow and Singer, 1984). Conclusively, the TCM precursors, formed through direct reaction of molecular ozone, were distributed in the low MW fractions.

\subsection{2. $\cdot$ OH radicals reactions}

'OH radicals also played significant roles in TCM precursor's formation during ozonation. Because the rate constants of $\mathrm{OH}$ radicals oxidations are much higher $\left(10^{12}\right.$ $10^{14} \mathrm{M}^{-1} \mathrm{~s}^{-1}$ ) than other oxidations, $\mathrm{OH}$ radicals can rapidly react with compounds such as aromatic hydrocarbons, unsaturated compounds, and aliphatic alcohols unselectively (Haag and Yao, 1992). The addition of ${ }^{\circ} \mathrm{OH}$ radicals to aromatic sites and the abstraction of hydrogen from hydrocarbons may be involved in the reactions between humic substances and $\mathrm{OH}$ radicals (Fukushima and Tatsumi, 2001). 'OH radicals addition can produce the phenol, dihydroxycyclohexadienyl radical and coupling products. In the presence of $\mathrm{O}_{2}$, the abstraction of hydrogen atom from alkyl groups yields alcohols and epoxides.

GC/MS analysis in this study demonstrated the formation of alcohols (Fig. 6b). Combining with FTIR characterization, the formation of intermediate products such as phenols, alcohols and epoxides were verified. These species would steadily react with chlorine and be responsible for the enhancement of TCM precursors by the $\mathrm{OH}$ radicals oxidations (Kleiser and Frimmel, 2000).

\section{Conclusions}

1. Bicarbonate inhibited the DOC removal via scavenging 'OH radicals in the ozonation process. Furthermore, bicarbonate inhibited the formation of TCM precursors in the initial ozonation periods and decreased subsequent TCM formation during chlorination.

2. TCMFP increased in each MW fraction of FA in the initial 20 min of ozonation process. However, in the presence of bicarbonate, the amount of TCM precursors in MW $>30 \mathrm{kDa}$ of FA decreased after ozonation. These phenomena indicated that the inhibiting effect of bicarbonate on the formation of TCM precursors mainly occurred in the high MW fraction.

3. The TCMFP of organic compounds were influenced by their functional characteristics rather than DOC and $\mathrm{UV}_{254}$ during the ozonation. The organic compounds with the $\mathrm{C}-\mathrm{O}$ structure, such as phenols, alcohols and epoxides, were the TCM precursors inhibited by bicarbonate during the ozonation.

\section{Acknowledgements}

This research was supported by the Funds for Creative Research Groups of China (Grant No. 50621804) and the National Natural Science Foundation of China (Grant No. 50538090).

\section{References}

Aiken, G.R., McKnight, D.M., Wershaw, R.L., MacCarthy, P., 1985. Humic Substances in Soils Sediments and Water. John Wiley, New York.

Arslan-Alaton, I., Kornmuller, A., Jekel, M.R., 2002. Ozonation of spent reactive dye-baths: effect of $\mathrm{HCO}_{3}^{-} / \mathrm{CO}_{3}^{2-}$ alkalinity. J. Environ. Eng. ASCE 128, 689-696.

Bothe, E., Schuchmann, M.N., Schulte-Frohlinde, D., Von Sonntag, C., 1978. $\mathrm{HO}_{2}$ elimination from a-hydroxyalkylperoxyl radicals in aqueous solution. J. Photochem. Photobiol. A 28, 639-644.

Buxton, G.V., Greenstock, C.L., Helman, W.P., Ross, A.B., 1988. Critical review of rate constants for reactions of hydrated electrons, hydrogen atoms and hydroxyl radicals $\left(\mathrm{OH}^{\mathrm{o}} / \mathrm{O}^{\mathrm{o}^{-}}\right)$in aqueous solution. J. Phys. Chem. Ref. Data. 17, 513-886.

Chang, C.N., Ma, Y.S., Zing, F.F., 2002. Reducing the formation of disinfection by-products by pre-ozonation. Chemosphere 46, 21-30.

Chiang, P.C., Chang, E.E., Liang, C.H., 2002. NOM characteristics and treatabilities of ozonation processes. Chemosphere 46, 929-936.

EPA, 1984. EPA Method 625. Base/Neutrals and Acids. EPA/Waterscience, US Environmental Protection Agency, Washington, DC.

EPA, 1998. EPA Method 551.1. Determination of Chlorination Disinfection Byproducts, Chlorinated Solvents, and Halogenated Pesticides/Herbicides in Drinking Water by Liquid-Liquid Extraction and Gas Chromatography with Electron-Capture Detection. EPA/600/R-95-131, US Environmental Protection Agency, Washington, DC.

Fukushima, M., Tatsumi, K., 2001. Degradation characteristics of humic acid during photo-fenton processes. Environ. Sci. Technol. 35, 36833690.

Gottschalk, G., Libra, J.A., Saupe, A., 2002. Ozonation of Water and Waste Water. Willey-VCH, Weinheim.

Hofmann, R., Andrew, R.C., 2006. Impact of $\mathrm{H}_{2} \mathrm{O}_{2}$ and (bi)carbonate alkalinity on ammonia's inhibition of bromate formation. Water Res. 40, 3343-3348.

Haag, E.R., Yao, C.C.D., 1992. Rate constants for reaction of hydroxyl radicals with several drinking water contaminants. Environ. Sci. Technol. 26, 1005-1013.

Hua, G., Reckhow, D.A., 2007. Characterization of disinfection byproduct precursors based on hydrophobicity and molecular size. Environ. Sci. Technol. 41, 3309-3315.

Kleiser, G., Frimmel, F.H., 2000. Removal of precursors for disinfection by-products (DBPs) - differences between ozone- and OH-radicalinduced oxidation. Sci. Total. Environ. 256, 1-9.

Ko, Y.W., Chiang, P.C., Chuang, C.L., Chang, E.E., 2000. Kinetics of the reaction between ozone and $p$-hydroxybenzoic acid in a semibatch reactor. Ind. Eng. Chem. Res. 39, 635-641.

Lykins, J., Benjamin, W., Koffskey, W.E., Patterson, K.S., 1994. Alternative disinfectants for drinking water treatment. J. Environ. Eng. ASCE 120, 745-758.

Reckhow, D.A., Singer, P.C., 1984. Mechanisms of organic halide formation during fulvic acid chlorination and implications with respect to pre-ozonation. In: Jolley, R.L., Bull, R.J., Davis, W.P., Katz, S., Roberts, M.H., Jacobs, V. (Eds.), . In: Water Chlorination: Chemistry, Environmental Impact and Health Effects, vol. 5. Lewis Publishers Inc., Chelsea, MI, pp. 229-1257.

Reckhow, D.A., Legube, B., Singer, P.C., 1986. The ozonation of organic halide precursors: effect of bicarbonate. Water Res. 20, 987-998.

Reckhow, D.A., Singer, P.C., 1999. Control of disinfection by-product formation using ozone. In: Singer, P.C. (Ed.), Formation and Control of Disinfection By-products in Drinking Water. American Water Works Association, Denver, CO, pp. 179-204.

Rook, J.J., 1974. Formation of haloforms during chlorination of natural waters. Water Treat. Exam. 23, 234-245.

Silverstein, R.M., Webster, F.X., 1998. Spectrometric Identification of Organic Compounds. John Wiley, New York. 